\title{
KEBUTUHAN INVESTOR TERHADAP INFORMASI KINERJA PEMERINTAH DAERAH KABUPATEN BANYUMAS DALAM PENGAMBILAN KEPUTUSAN INVESTASI
}

\author{
Oman Rusmana ${ }^{1}$, Alfian Pradana Baskoro Putra, dan Sukirman \\ Jurusan Akuntansi, Fakultas Ekonomi, Universitas Jenderal Soedirman \\ 1omanrsm@gmail.com
}

\section{ABSTRACT}

This study is a research used mixed methods that focused to combine two approaches, quantitative and qualitative on user of Local Government Finance Report (LKPD) in Banyumas Regency. The purpose of this study were determine the needs of investors, investor information that used in $L K P D$, relationship between respondents and their description of reading $L K P D$, suitability of infrastructure information in $L K P D$ to user needs, and the factors that affect the infrastructure reporting in LKPD.

Based of research and data analysis using Chi Square test (Fisher's Exact), descriptive statistics methods and qualitative analysis show that: (1) The need for investors to invest in Banyumas is a good investment climate, (2) The information used by investors in the LKPD Banyumas in making investment decisions are government policy, evaluation of services, information infrastructure, and information regarding the BPK audit opinion LKPD, (3) There is a relationship between readers / non-readers $L K P D$ and the category of respondents, (4) There is a relationship between respondents by reason of reading $L K P D$, (5) There is the relationship between the importance of infrastructure information and respondents of readers $L K P D,(6)$ There was no relationship between the time required to read $L K P D$ and the importance of information infrastructure, (7) Disclosure aspects of financial infrastructure in the LKPD Banyumas Regency is not appropriate with the needs of users, (8) Disclosure aspects of non-financial infrastructure in Banyumas LKPD is not fully appropriate with the needs of users (9) Factors that affecting disclosure of infrastructure in LKPD of Banyumas Regency are: council recommendation, Government Accounting Standards, recommendation of Badan Pemeriksa Keuangan and local government policy.

Keywords: needs of investor, infrastructure information, Local Government Finance Report (LKPD), investment decisions, Government Accounting Standards, disclosure aspects.

\section{PENDAHULUAN}

Reformasi di berbagai bidang yang sedang berlangsung di Indonesia telah membawa perubahan terhadap sistem politik, sosial, kemasyarakatan serta ekonomi sehingga menimbulkan tuntutan yang beragam terhadap pengelolaan pemerintahan yang baik. Salah satu agenda reformasi yaitu adanya sistem pengelolaan keuangan daerah. Hal tersebut di tandai dengan diterbitkannya Undang-undang Nomor 17 Tahun 2003 tentang Keuangan Negara, Undang-Undang Nomor 1 Tahun 2004 tentang Perbendaharaan Negara, Undang-Undang Nomor 15 Tahun 2004 tentang Pemeriksaan Pengelolaan dan Tanggung Jawab Keuangan Negara. Di samping itu, Undang-undang No.25 Tahun 2004 tentang Sistem Perencanaan Pembangunan Nasional (SPPN) dijelaskan juga bahwasanya dalam sistem perencanaan pembangunan nasional dan daerah mengamanatkan adanya partisipasi dan keterlibatan masyarakat dalam proses perencanaan pembangunan. 
Dalam pengelolaan keuangan harus mengacu kepada Peraturan Pemerintah

JURNAL

MANAJEMEN

INDONESIA

Vol. 15 - No.2

Agustus 2015
No. 58 tahun 2005 tentang Pengelolaan Keuangan Daerah dan Permendagri No.13 tahun 2006 tentang pedoman pengelolaan keuangan daerah, mulai dari penyusunan anggaran, pelaksanaan anggaran sampai pertanggungjawaban penggunaan anggaran daerah. Sedangkan penyajian Laporan Keuangan Pemerintah Daerah (LKPD) harus mengacu kepada Peraturan Pemerintah No.24 tahun 2005 (terbaru adalah Peraturan Pemerintah No.71 tahun 2010) tentang standar akuntansi pemerintah.

Penelitian ini berkonsentrasi pada infrastruktur, sebab para investor yang sedang atau akan berinvestasi di suatu daerah sangat membutuhkan ketersediaan infrastruktur yang dapat mendukung dan menunjang perkembangan investasinya, seperti tanah, jalan, jembatan, jaringan dan instalasi air, instalasi listrik dan telepon. Sehingga dalam pengambilan keputusan investasinya, investor membutuhkan informasi mengenai infrastruktur di suatu daerah yang dapat diperoleh di dalam LKPD. Selain itu, sejumlah besar uang masyarakat diinvestasikan dalam aset seperti jalan, jembatan, tanah, dan gedung. Investasi dalam infrastruktur publik membantu dalam meningkatkan produktivitas (Conrad dan Seitz, 1994). Infrastruktur dianggap penting bagi pembangunan ekonomi dan sosial (Bank Dunia, 1994). Namun, terdapat kekurangan dalam studi yang telah menyelidiki preferensi pengguna laporan tentang model pelaporan infrastruktur (Chatterjee, 2011). Selain itu penelitian ini berkonsentrasi pada pemerintah daerah, sebab sebagian besar layanan penting seperti jalan, jembatan, dan persediaan air disediakan oleh pemerintah daerah. Sekitar 70 persen dari nilai aset dari pemerintah daerah terdiri dari aset infrastruktur (Pallot, 1997). Pemerintah daerah juga memiliki jumlah yang besar dari aset infrastruktur. Sebagai contoh, sekitar $30 \%$ aset infrastruktur berasal dari jalan, jaringan, dan instalasi di Kabupaten Banyumas dan, secara total, aset infrastruktur senilai Rp 2.928.764.231.226,10 pada tahun 2010 (LKPD Kabupaten Banyumas, 2010).

Terkait hal tersebut, penulis menilai bahwa LKPD belum memenuhi kebutuhan pengguna LKPD. Untuk itulah penelitian ini dilakukan dengan tujuan untuk mengetahui kesesuaian aspek pengungkapan informasi infrastruktur keuangan di dalam LKPD Kabupaten Banyumas dengan kebutuhan pengguna. Selain karena pertimbangan belum ada penelitian yang sejenis, pertimbangan lain adalah untuk memberi masukan kepada pemerintah daerah mengenai pengungkapan informasi infrastruktur yang dibutuhkan dalam LKPD Kabupaten Banyumas.

Perumusan Masalah Penelitian ini adalah:

1. Apa kebutuhan investor dalam berinvestasi di Kabupaten Banyumas?

2. Informasi apakah di dalam LKPD Kabupaten Banyumas yang digunakan oleh investor dalam pengambilan keputusan investasi?

3. Apakah terdapat hubungan antara pembaca/bukan pembaca LKPD dengan kategori responden?

4. Apakah terdapat hubungan antara kategori responden dengan alasan membaca LKPD?

5. Apakah terdapat hubungan antara pentingnya informasi infrastruktur dengan kategori responden pembaca LKPD?

6. Apakah terdapat hubungan antara waktu yang dibutuhkan untuk membaca LKPD dengan pentingnya informasi infrastruktur?

7. Apakah aspek pengungkapan informasi infrastruktur keuangan di dalam LKPD Kabupaten Banyumas telah sesuai dengan kebutuhan pengguna?

8. Apakah aspek pengungkapan informasi infrastruktur non-keuangan di dalam LKPD Kabupaten Banyumas telah sesuai dengan kebutuhan pengguna?

9. Faktor-faktor apakah yang mempengaruhi pelaporan infrastruktur dalam LKPD Kabupaten Banyumas? 


\section{METODE PENELITIAN}

Objek penelitian adalah penilaian pengguna LKPD terhadap pengungkapan informasi infrastruktur di dalam LKPD Kabupaten Banyumas. Penelitian ini dilakukan menggunakan metode campuran/mixed methods. Mixed methods adalah metode yang difokuskan untuk mengkombinasikan dua pendekatan, yaitu kuantitatif dan kualitatif. Hal ini dilakukan untuk memperluas pandangan dan menambah pemahaman yang lebih baik tentang keduanya atau digunakan untuk memberikan penjelasan yang lebih baik dengan pendekatan satu dengan pendekatan yang lain (Bryman, 2006; Tashakkori dan Teddlie, 2003).

Dalam penelitian ini, model yang digunakan adalah model eksplanatoris sekuensial yaitu merupakan model yang diterapkan dengan pengumpulan dan analisis data kuantitatif pada tahap pertama yang diikuti oleh pengumpulan dan analisis data kualitatif pada tahap kedua yang dibangun berdasarkan hasil awal kuantitatif, hal tersebut peneliti lakukan untuk memperkuat hasil penelitian kuantitatif.

Populasi penelitian ini adalah pengguna LKPD. Metode penetapan sampel yang digunakan adalah convenience sampling. Jumlah sampel yang disebar adalah sebanyak 5 kepada masing-masing investor yang bergerak di bidang jasa, dagang, dan manufaktur yaitu Hotel Horison, PT. Rita Ritelindo, Gubug Makan Mang Engking, PT. Bina Agung Damar Buana, dan PT. Harapan Jaya Globalindo, sebanyak 10 disebar kepada anggota DPRD, sebanyak 10 disebar kepada pegawai DPPKAD, sebanyak 10 disebar kepada dosen, dan sebanyak 10 disebar kepada mahasiswa. Penyebaran kuisioner dilakukan secara langsung oleh peneliti, sehingga peneliti memperoleh 45 kuisioner yang diisi lengkap dan layak untuk diolah datanya. Kriteria mahasiswa yang dijadikan sampel adalah mahasiswa semester 5 atau lebih yang telah mengambil mata kuliah Akuntansi Sektor Publik dan mengetahui LKPD.

Sampel data kualitatif adalah dengan mewawancarai kelima investor yang terdiri dari Hotel Horison, PT. Rita Ritelindo, Gubug Makan Mang Engking, PT. Bina Agung Damar Buana, dan PT. Harapan Jaya Globalindo.

\subsection{Teknik Analisis Data}

\subsubsection{Analisis Responden}

Dalam analisa responden digunakan Chi Square atau uji Fisher's Exact dengan metode Monte Carlo.

\subsubsection{Analisis Data Kuantitatif}

Metode analisis data untuk data penelitian kuantitatif menggunakan metode analisis statistik deskriptif.

\subsubsection{Analisis Data Kualitatif}

Analisis data dilakukan menggunakan analisis interaktif seperti yang dikembangkan oleh Miles dan Huberman (2007). Analisa data dilakukan dengan melalui prosedur sebagai berikut:
a) Reduksi data.
b) Penyajian data (display data).
c) Penarikan kesimpulan/verifikasi. 
JURNAL

MANAJEMEN INDONESIA

Vol. 15 - No.2

Agustus 2015

\section{HASIL DAN PEMBAHASAN}

Hasil wawancara mengenai kebutuhan investor dalam berinvestasi di Kabupaten Banyumas menunjukkan bahwa investor membutuhkan iklim investasi yang baik terutama dalam hal ketersediaan infrastruktur, seperti tanah, fasilitas transportasi, ketersediaan energi, listrik, air, peralatan dan mesin berat, material lain, dan ketersediaan sarana komunikasi yang menunjang perkembangan perusahaan. Di samping itu, investor juga membutuhkan pelayanan pajak dan pelayanan perizinan yang baik, informasi perkembangan pariwisata, tersedianya SDM, informasi lelang dari pemda, perda mengenai investasi, dan informasi kegiatan pemerintah daerah.

Demikian halnya dengan hasil wawancara mengenai informasi yang digunakan investor di dalam LKPD Kabupaten Banyumas dalam pengambilan keputusan investasi menunjukkan bahwa dalam pengambilan keputusan investasi, investor menggunakan informasi dari Pemerintah Kabupaten Banyumas antara lain kebijakan pemerintah dibidang investasi, perpajakan, serta ekspor impor; evaluasi pelayanan (termasuk biaya jasa) yang diberikan pemda, seperti: pelayanan perizinan dan tarifnya; informasi ketersediaan infrastruktur seperti informasi mengenai tanah, informasi jalan, listrik, air, dan akses-akses yang dapat mendukung investasi; informasi potensi unggulan daerah; prediksi pertumbuhan ekonomi daerah; perencanaan pemda beberapa tahun ke depan; prediksi pertumbuhan pendapatan pemda; dan informasi mengenai opini audit BPK atas LKPD.

Dari kedua hasil wawancara tersebut menunjukkan bahwa salah satu kebutuhan investor terhadap informasi mengenai pemerintah daerah yang digunakan dalam pengambilan keputusan investasi serta dapat mendukung usaha, bisnis, serta perkembangan investasinya adalah informasi mengenai ketersediaan infrastruktur di Kabupaten Banyumas. Hal ini sesuai dengan kajian teori ekonomi pembangunan menurut Marzuki (2005) dan Prof. Sjafrizal (2008) yang mengatakan bahwa untuk menciptakan dan meningkatkan kegiatan ekonomi diperlukan sarana infrastruktur yang memadai.

\subsection{Analisis Responden}

Secara statistik terdapat hubungan antara 'Membaca/Tidak Membaca' LKPD dan 'kategori responden' (Uji Fisher's Exact $=16,582 ; p=$ $0,001)$. Hal tersebut menunjukkan bahwa $p<0,05$, maka $\mathbf{H 1}$ diterima. Hasil penelitian ini menunjukkan bahwa terdapat hubungan antara pembaca/bukan pembaca LKPD dengan kategori responden. Hal itu tidak sesuai dengan penelitian yang dilakukan oleh Chatterjee (2011) yang menyimpulkan bahwa tidak terdapat hubungan antara pembaca/bukan pembaca LKPD dengan kategori responden.

Secara statistik, terdapat hubungan antara 'kategori responden' dan 'alasan dibalik membaca LKPD' (Uji Fisher's Exact $=34,417 ; p=0,000 ; p<0,05$ ). Hal tersebut menunjukkan bahwa $p<0,05$, maka H2 diterima. Hasil penelitian ini menunjukkan bahwa terdapat hubungan antara kategori responden dengan alasan membaca LKPD. Hal itu sesuai dengan penelitian yang dilakukan oleh Chatterjee (2011) yang menyimpulkan bahwa terdapat hubungan antara kategori responden dengan alasan membaca LKPD. 
Secara statistik tidak terdapat hubungan yang signifikan antara 'waktu yang dibutuhkan untuk membaca LKPD' dan 'seberapa penting informasi infrastruktur' (Uji Fisher's Exact $=10,948 ; p=0,112 ; p>0,05$ ). Hal tersebut menunjukkan bahwa $\mathrm{p}>0,05$, maka $\mathbf{H 4}$ ditolak. Hal ini menunjukkan bahwa semua pembaca tanpa melihat waktu yang dibutuhkan dalam membaca LKPD, membaca tentang informasi 'infrastruktur'. Hasil penelitian ini menunjukkan bahwa tidak terdapat hubungan antara waktu yang dibutuhkan untuk membaca LKPD dengan pentingnya informasi infrastruktur. Hal itu tidak sesuai dengan penelitian yang dilakukan oleh Chatterjee (2011) yang menyimpulkan bahwa terdapat hubungan antara waktu yang dibutuhkan untuk membaca LKPD dengan pentingnya informasi infrastruktur.

3.2. Informasi Infrastruktur yang Penting dan Pelaporan Informasi Infrastruktur tersebut di dalam LKPD Kabupaten Banyumas

\subsubsection{Informasi Infrastruktur Keuangan}

\subsubsection{Metode penilaian yang penting dan pengungkapannya di dalam LKPD Kabupaten Banyumas}

\begin{tabular}{c|l|c|c|c}
\hline No & $\begin{array}{l}\text { Item Informasi } \\
\text { Infrastruktur }\end{array}$ & $\begin{array}{c}\text { Mea } \\
\mathrm{n}\end{array}$ & S.D. & $\begin{array}{c}\text { Pengungkapan LKPD Kab. Banyumas Tahun 2009- } \\
2010\end{array}$ \\
\hline \multicolumn{2}{l}{ I. Informasi Keuangan } & & & \\
\hline \multicolumn{2}{l}{ A. Penilaian } & & & \\
\hline 1 & Biaya historis/kos historis & $\mathbf{3 . 9 3}$ & $\begin{array}{c}0.58 \\
0\end{array}$ & Ya \\
\hline 2 & Harga pembelian terakhir & $\mathbf{4 . 0 9}$ & $\begin{array}{c}0.70 \\
1\end{array}$ & Tidak \\
\hline \multirow{2}{*}{3} & $\begin{array}{l}\text { Nilai jual objek pajak - } \\
\text { tanah }\end{array}$ & $\mathbf{3 . 8 4}$ & $\begin{array}{c}0.73 \\
7\end{array}$ & Tidak \\
\hline \multirow{2}{*}{4} & Hasil valuasi penilai & $\mathbf{4 . 0 2}$ & $\begin{array}{c}0.69 \\
0\end{array}$ & Ya \\
\cline { 2 - 5 }
\end{tabular}

Responden menganggap 'harga pembelian terakhir' menjadi metode penilaian yang paling 'penting'. Kabupaten Banyumas melaporkan penilaian infrastruktur berdasarkan 'biaya historis' dan 'hasil valuasi penilai', Kabupaten Banyumas tidak melaporkan informasi infrastruktur didasarkan pada dua metode penilaian lainnya dalam LKPD (Tabel 1).

Kabupaten Banyumas melaporkan penilaian infrastruktur berdasarkan 'biaya historis' yaitu ditunjukkan dengan basis pengukuran aset tetap yang mendasari laporan keuangan bahwa aset tetap dicatat sebesar biaya perolehan (LKPD Kab. Banyumas, 2010). Kemudian Kabupaten Banyumas juga melaporkan penilaian infrastruktur berdasarkan 'hasil valuasi penilai' yaitu ditunjukkan bahwa pada tahun 2010, dilakukan penilaian atas aset tetap yang belum mencantumkan nilai.

Hasil penelitian ini tidak sesuai dengan penelitian yang dilakukan oleh Chatterjee (2011) yang menunjukkan bahwa responden menganggap 'biaya pertukaran' menjadi metode penilaian yang paling 'penting'.
JURNAL

MANAJEMEN

INDONESIA

Vol. 15 - No.2

Agustus 2015

\section{Tabel 1.}

Metode penilaian yang penting dan pengungkapannya di dalam LKPD Kabupaten Banyumas

\section{5}




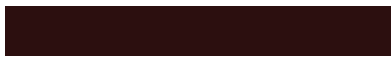

JURNAL

MANAJEMEN

INDONESIA

Vol. 15 - No.2

Agustus 2015

Tabel 2.

Metode penyusutan yang penting dan pengungkapannya di dalam LKPD Kabupaten

Tabel 3.

Informasi keuangan

diaudit

yang penting

dan pengungkapannya

di dalam

LKPD Kabupaten
3.2.1.2. Metode penyusutan yang penting dan pengungkapannya di dalam LKPD Kabupaten Banyumas

\begin{tabular}{c|l|c|c|c}
\hline No & $\begin{array}{l}\text { Item Informasi } \\
\text { Infrastruktur }\end{array}$ & $\begin{array}{c}\text { Mea } \\
\mathrm{n}\end{array}$ & S.D. & $\begin{array}{c}\text { Pengungkapan LKPD Kab. Banyumas Tahun } \\
\text { 2009-2010 }\end{array}$ \\
\hline \multicolumn{1}{l}{ I. Informasi Keuangan } & & & \\
\hline \multicolumn{2}{l|}{ B. Metode penyusutan } & & & \\
\hline 5 & Metode garis lurus & $\mathbf{3 . 9 8}$ & $\begin{array}{c}0.89 \\
2\end{array}$ & Tidak \\
\hline 6 & $\begin{array}{l}\text { Metode saldo menurun } \\
\text { ganda }\end{array}$ & $\mathbf{3 . 6 2}$ & $\begin{array}{c}0.68 \\
4\end{array}$ & Tidak \\
\hline 7 & Metode unit produksi & $\mathbf{3 . 3 1}$ & $\begin{array}{c}0.99 \\
6\end{array}$ & Tidak \\
\cline { 2 - 5 }
\end{tabular}

Responden menganggap 'metode garis lurus' menjadi yang paling 'penting'. Sementara Kabupaten Banyumas tidak menyusutkan infrastrukturnya menggunakan 'metode penyusutan' (Tabel 4.2). Hal itu ditunjukkan pada penerapan kebijakan akuntansi mengenai penyusutan bahwa Neraca Pemerintahan Kabupaten Banyumas tahun 2009 tidak menyajikan akumulasi aset tetap dikarenakan Pemerintah Kabupaten Banyumas belum menetapkan kebijakan akuntansi yang berkaitan dengan penyusutan aset tetap (LKPD Kab. Banyumas, 2010). Sehingga Kabupaten Banyumas melaporkan aset tetap 'tanpa penyusutan' dengan menggunakan 'biaya historis'.

Hasil penelitian ini sesuai dengan penelitian yang dilakukan oleh Chatterjee (2011) yang menunjukkan bahwa mayoritas responden memilih metode 'penyusutan' dengan 'metode garis lurus' menjadi yang paling 'penting'.

\subsubsection{Informasi keuangan diaudit yang penting dan} pengungkapannya di dalam LKPD Kabupaten Banyumas

\begin{tabular}{c|l|c|c|c}
\hline $\begin{array}{c}\text { No } \\
\text { I. Informasi Keuangan }\end{array}$ & $\begin{array}{c}\text { Mea } \\
\mathrm{n}\end{array}$ & S.D. & $\begin{array}{c}\text { Pengungkapan LKPD Kab. } \\
\text { Banyumas Tahun 2009-2010 }\end{array}$ \\
\hline \multicolumn{1}{l}{ C. Informasi keuangan yang diaudit } & & & \\
\hline 8 & $\begin{array}{l}\text { Realisasi belanja pemeliharaan infrastruktur } \\
\text { tahun berjalan }\end{array}$ & 4.29 & $\begin{array}{c}0.58 \\
9\end{array}$ & Ya \\
\hline 9 & $\begin{array}{l}\text { Realisasi pengungkapan terpisah pada } \\
\text { belanja pemeliharaan rutin dan tidak rutin }\end{array}$ & 3.91 & $\begin{array}{c}0.63 \\
3\end{array}$ & $\mathrm{Ya}$ \\
\hline \multirow{2}{*}{10} & Arus kas terkait infrastruktur & 3.89 & $\begin{array}{c}0.77 \\
5\end{array}$ & $\mathrm{Ya}$ \\
\cline { 2 - 6 }
\end{tabular}

'Realisasi belanja pemeliharaan infrastruktur tahun berjalan' dianggap paling 'penting'. Kabupaten Banyumas mengungkapkan semua 'informasi keuangan yang diaudit' tersebut. Kabupaten Banyumas mengungkapkan realisasi belanja tersebut pada Laporan Realisasi Anggaran yang terkandung dalam belanja barang untuk belanja pemeliharaan rutin dan belanja modal untuk belanja pemeliharaan tidak rutin. Arus kas terkait infrastruktur juga tertuang di dalam arus kas dari investasi aset non keuangan pada Laporan Arus Kas ((LKPD Kab. Banyumas, 2010).

Hasil penelitian ini sesuai dengan penelitian yang dilakukan oleh Chatterjee (2011) yang menunjukkan bahwa responden menganggap 'realisasi belanja pemeliharaan infrastruktur tahun berjalan' menjadi 'informasi keuangan yang diaudit' yang paling 'penting'. 
3.2.1.4. Informasi anggaran yang penting dan pengungkapannya di dalam LKPD Kabupaten Banyumas

\begin{tabular}{c|l|c|c|c}
\hline $\begin{array}{c}\text { No } \\
\cdot\end{array}$ & Item Informasi Infrastruktur & $\begin{array}{c}\text { Mea } \\
\mathrm{n}\end{array}$ & S.D. & $\begin{array}{c}\text { Pengungkapan LKPD Kab. } \\
\text { Banyumas Tahun 2009- } \\
2010\end{array}$ \\
\hline I. Informasi Keuangan & & & \\
\hline D. Informasi keuangan yang tidak diaudit & & & \\
\hline 11 & $\begin{array}{l}\text { Rencana pemeliharaan infrastruktur lima tahun } \\
\text { menguraikan pemeliharaan yang diperlukan } \\
\text { setiap tahun }\end{array}$ & 3.80 & $\begin{array}{c}0.66 \\
1\end{array}$ & Tidak \\
\hline 12 & Belanja pemeliharaan ditangguhkan & 3.33 & $\begin{array}{c}0.73 \\
9\end{array}$ & Tidak \\
\hline 13 & $\begin{array}{l}\text { Pengungkapan pemeliharaan yang diperlukan } \\
\text { setiap tahun }\end{array}$ & 3.91 & $\begin{array}{c}0.66 \\
8\end{array}$ & Ya \\
\hline 14 & $\begin{array}{l}\text { Biaya untuk mencapai tingkat target pelayanan } \\
\text { jika berbeda dari yang sebenarnya }\end{array}$ & 3.67 & $\begin{array}{c}0.76 \\
9\end{array}$ & Tidak \\
\hline 15 & $\begin{array}{l}\text { Anggaran untuk realisasi pengeluaran } \\
\text { infrastruktur }\end{array}$ & $\mathbf{4 . 0 2}$ & $\begin{array}{c}0.58 \\
3\end{array}$ & Ya \\
\hline \multirow{2}{*}{16} & $\begin{array}{l}\text { Komitmen belanja modal dalam hal } \\
\text { infrastruktur, seperti kontrak yang sudah masuk } \\
\text { sebelumnya }\end{array}$ & 3.91 & $\begin{array}{c}0.79 \\
3\end{array}$ & Ya \\
\hline \multirow{2}{*}{17} & $\begin{array}{l}\text { Pentingnya Kerangka Pengeluaran Jangka } \\
\text { Menengah (KPJM) dalam perencanaan anggaran } \\
\text { infrastruktur }\end{array}$ & 3.96 & $\begin{array}{c}0.67 \\
3\end{array}$ & Tidak \\
\cline { 2 - 6 }
\end{tabular}

Responden menganggap 'anggaran untuk realisasi pengeluaran infrastruktur' menjadi yang paling 'penting'. Kabupaten Banyumas hanya mengungkapkan 'pengungkapan pemeliharaan yang diperlukan setiap tahun', 'anggaran untuk realisasi pengeluaran infrastruktur', dan 'komitmen belanja modal dalam hal infrastruktur, seperti kontrak yang sudah masuk sebelumnya'. Hal tersebut ditunjukkan dengan anggaran belanja barang dan belanja modal yang tercantum dalam Laporan Realisasi Anggaran serta penjelasan mengenai belanja tersebut di dalam Catatan atas Laporan Keuangan.

Hasil penelitian ini sesuai dengan penelitian yang dilakukan oleh Chatterjee (2011) yang menunjukkan bahwa responden menganggap 'anggaran untuk realisasi pengeluaran infrastruktur' menjadi informasi anggaran yang paling 'penting'.

\subsubsection{Informasi infrastruktur non-keuangan}

\subsubsection{Informasi umum non-keuangan yang penting dan} pengungkapannya di dalam LKPD Kabupaten Banyumas

\begin{tabular}{c|l|c|c|c}
\hline No & Item Informasi Infrastruktur & $\begin{array}{c}\text { Mea } \\
\mathrm{n}\end{array}$ & S.D. & $\begin{array}{c}\text { Pengungkapan LKPD } \\
\text { Kab. Banyumas } \\
\text { Tahun 2009-2010 }\end{array}$ \\
\hline II. Informasi Non-Keuangan & & & \\
\hline E. Informasi umum non-keuangan & & 3.98 & $\begin{array}{c}0.69 \\
0\end{array}$ & Ya \\
\hline 18 & $\begin{array}{l}\text { Informasi tentang kebutuhan untuk infrastruktur } \\
\text { baru }\end{array}$ & $\mathbf{3 . 8 9}$ & $\begin{array}{c}0.68 \\
2\end{array}$ & Ya \\
\hline 19 & Infrastruktur kehidupan ekonomi & $\mathbf{4 . 2 2}$ & $\begin{array}{c}0.63 \\
6\end{array}$ & Tidak \\
\hline 20 & $\begin{array}{l}\text { Rencana pengelolaan aset disertifikasi oleh ahli } \\
\text { independen }\end{array}$ & $\mathbf{4 . 2 7}$ & $\begin{array}{c}0.65 \\
4\end{array}$ & Ya \\
\hline 21 & $\begin{array}{l}\text { Deskripsi fisik aset infrastruktur, seperti luas tanah, } \\
\text { luas bangunan, panjang irigasi, panjang jembatan, } \\
\text { kilometer jalan, panjang pipa atau kabel }\end{array}$ & $\mathbf{4 . 1 6}$ & $\begin{array}{c}0.47 \\
5\end{array}$ & Ya \\
\hline 22 & Belanja infrastruktur & $\mathbf{3 . 9 3}$ & $\begin{array}{c}0.72 \\
0\end{array}$ & Ya \\
\hline 23 & $\begin{array}{l}\text { Informasi mengenai apakah aset infrastruktur telah } \\
\text { meningkat selama tahun fiskal sekarang }\end{array}$ & $\mathbf{3 . 9 3}$ & $\begin{array}{c}0.65 \\
4\end{array}$ & Tidak \\
\hline 24 & $\begin{array}{l}\text { Penilaian implikasi jangka panjang dari praktek } \\
\text { manajemen infrastruktur sekarang }\end{array}$ & $\mathbf{4 . 3 1}$ & $\begin{array}{c}0.63 \\
3\end{array}$ & Ya \\
\hline 25 & $\begin{array}{l}\text { Informasi mengenai penguasaan infrastruktur, } \\
\text { apakah pusat, provinsi dan kabupaten/kota }\end{array}$ &
\end{tabular}

JURNAL

MANAJEMEN

INDONESIA

Vol. 15 - No.2

Agustus 2015

\section{Tabel 4.}

Informasi anggaran

yang penting

dan pengungkapannya

di dalam LKPD

Kabupaten Banyumas
Tabel 5.

Informasi umum

non-keuangan

yang penting

dan pengungkapannya

di dalam LKPD

Kabupaten Banyumas 
JURNAL

MANAJEMEN

INDONESIA

Vol. 15 - No.2

Agustus 2015

Responden menganggap 'informasi mengenai penguasaan infrastruktur, apakah pusat, provinsi dan kabupaten/kota' menjadi yang paling 'penting'. Kabupaten Banyumas melaporkan 'informasi mengenai penguasaan infrastruktur, apakah pusat, provinsi dan kabupaten/kota', 'deskripsi fisik aset infrastruktur, seperti luas tanah, luas bangunan, panjang irigasi, panjang jembatan, kilometer jalan, panjang pipa atau kabel', 'belanja infrastruktur', 'informasi tentang kebutuhan untuk infrastruktur baru', 'informasi mengenai apakah aset infrastruktur telah meningkat selama tahun fiskal sekarang', dan 'infrastruktur kehidupan ekonomi'.

Hal tersebut ditunjukkan di dalam Catatan atas Laporan Keuangan, seperti status kepemilikan tanah dimana Kabupaten Banyumas memiliki/menguasai 1.516 bidang tanah, penambahan aset atas penambahan aset dari belanja modal dan penambahan aset dari hibah/donasi, serta belanja infrastruktur yang digunakan untuk memperoleh pendapatan bagi daerah (LKPD Kab. Banyumas, 2009).

Hasil penelitian ini tidak sesuai dengan penelitian yang dilakukan oleh Chatterjee (2011) yang menunjukkan bahwa responden menganggap 'informasi tentang kebutuhan untuk infrastruktur baru' menjadi informasi umum non-keuangan yang paling 'penting'.

\subsubsection{Teknis infrastruktur yang penting dan pengungkapannya di dalam LKPD Kabupaten Banyumas}

Tabel 6.

Teknis infrastruktur yang penting dan pengungkapannya di dalam LKPD Kabupaten Banyumas

\begin{tabular}{c|l|c|c|c}
\hline No. & $\begin{array}{l}\text { Item Informasi } \\
\text { Infrastruktur }\end{array}$ & Mean & S.D. & $\begin{array}{c}\text { Pengungkapan LKPD Kab. Banyumas Tahun } \\
\text { 2009-2010 }\end{array}$ \\
\hline \multicolumn{1}{l|}{ II. Informasi Non-Keuangan } & & & \\
\hline F. Teknis infrastruktur & & & Ya \\
\hline 26 & $\begin{array}{l}\text { Siklus penggantian } \\
\text { (replacement) }\end{array}$ & 3.71 & $\begin{array}{c}0.58 \\
9\end{array}$ & Ya \\
\hline \multirow{2}{*}{27} & $\begin{array}{l}\text { Masa manfaat } \\
\text { infrastruktur }\end{array}$ & $\mathbf{4 . 1 1}$ & $\begin{array}{c}0.57 \\
3\end{array}$ & \\
\cline { 2 - 5 }
\end{tabular}

Kabupaten Banyumas melaporkan kedua teknis infrastruktur tersebut. Dalam Catatan atas Laporan Keuangan disebutkan bahwa aset tetap mencakup seluruh aset yang dimanfaatkan oleh pemerintah maupun untuk kepentingan publik yang mempunyai masa manfaat lebih dari satu tahun. Penggantian infrastruktur juga ditunjukkan keputusan Bupati Banyumas untuk menghapus barang milik Pemerintah Kabupaten Banyumas dan menambah aset tetap tersebut melalui belanja modal ((LKPD Kab. Banyumas, 2010).

Hasil penelitian ini tidak sesuai dengan penelitian yang dilakukan oleh Chatterjee (2011) yang menunjukkan bahwa responden menganggap 'siklus penggantian (replacement)' menjadi informasi teknis infrastruktur yang paling 'penting'. 
3.2.2.3. Indikator kinerja informasi yang penting dan pengungkapannya di dalam LKPD Kabupaten Banyumas

\begin{tabular}{c|l|c|c|c}
\hline No & Item Informasi Infrastruktur & $\begin{array}{c}\text { Mea } \\
\mathrm{n}\end{array}$ & S.D. & $\begin{array}{c}\text { Pengungkapan LKPD Kab. } \\
\text { Banyumas Tahun 2009-2010 }\end{array}$ \\
\hline \multicolumn{1}{l|l}{ Il. Informasi Non-Keuangan } & & & \\
\hline G. Indikator kinerja informasi & & & Tidak \\
\hline 28 & $\begin{array}{l}\text { Laporan kualitas layanan infrastruktur } \\
\text { oleh masyarakat }\end{array}$ & $\mathbf{3 . 9 8}$ & $\begin{array}{c}0.58 \\
3\end{array}$ & Tidak \\
\hline 29 & $\begin{array}{l}\text { Perbedaan antara target dan tingkat } \\
\text { pelayanan actual }\end{array}$ & $\mathbf{3 . 9 3}$ & $\begin{array}{c}0.72 \\
0\end{array}$ & Ya \\
\hline 30 & $\begin{array}{l}\text { Informasi komparatif antar } \\
\text { infrastruktur yang dipakai dan diganti }\end{array}$ & $\mathbf{3 . 9 6}$ & $\begin{array}{c}0.67 \\
3\end{array}$ & Ya \\
\hline \multirow{2}{*}{31} & $\begin{array}{l}\text { Ketersediaan/terganggunya } \\
\text { infrastruktur }\end{array}$ & $\mathbf{3 . 8 9}$ & $\begin{array}{c}0.68 \\
2\end{array}$ & Tidak \\
\hline \multirow{2}{*}{32} & $\begin{array}{l}\text { Layanan pengaduan/kepuasan } \\
\text { infrastruktur }\end{array}$ & $\mathbf{4 . 1 3}$ & $\begin{array}{c}0.69 \\
4\end{array}$ & \multicolumn{2}{c}{} \\
\cline { 2 - 6 }
\end{tabular}

Item informasi yang paling 'penting' adalah 'layanan pengaduan/kepuasan infrastruktur'. Kabupaten Banyumas mengungkapkan 'informasi komparatif antar infrastruktur yang dipakai dan diganti' dan 'ketersediaan/terganggunya infrastruktur'.

Hasil penelitian ini tidak sesuai dengan penelitian yang dilakukan oleh Chatterjee (2011) yang menunjukkan bahwa responden menganggap 'perbedaan antara target dan tingkat pelayanan aktual' menjadi indikator kinerja informasi yang paling 'penting'.

\subsubsection{Informasi keamanan infrastruktur}

\begin{tabular}{c|l|c|c|c}
\hline No & Item Informasi Infrastruktur & $\begin{array}{c}\text { Mea } \\
\mathrm{n}\end{array}$ & S.D. & $\begin{array}{c}\text { Pengungkapan LKPD Kab. } \\
\text { Banyumas Tahun 2009-2010 }\end{array}$ \\
\hline \multicolumn{1}{l}{ II. Informasi Non-Keuangan } & & & \\
\hline H. Informasi keamanan infrastruktur & & & \\
\hline 33 & $\begin{array}{l}\text { Kebijakan dalam hal inspeksi keamanan } \\
\text { infrastruktur }\end{array}$ & $\mathbf{3 . 8 0}$ & $\begin{array}{c}0.72 \\
6\end{array}$ & Ya \\
\hline \multirow{2}{*}{34} & $\begin{array}{l}\text { Kebijakan dalam hal penyediaan } \\
\text { infrastruktur pendidikan dan pelatihan } \\
\text { keamanan }\end{array}$ & $\mathbf{4 . 3 6}$ & $\begin{array}{c}0.57 \\
0\end{array}$ & Tidak \\
\hline 35 & $\begin{array}{l}\text { Jumlah insiden keamanan infrastruktur } \\
\text { terkait di tahun keuangan terakhir }\end{array}$ & 3.87 & $\begin{array}{c}0.58 \\
8\end{array}$ & Ya \\
\hline 36 & $\begin{array}{l}\text { Biaya insiden keamanan infrastruktur } \\
\text { terkait }\end{array}$ & 3.73 & $\begin{array}{c}0.65 \\
4\end{array}$ & Ya \\
\hline \multirow{2}{*}{37} & Biaya mengamankan infrastruktur & 3.91 & $\begin{array}{c}0.59 \\
6\end{array}$ & Ya \\
\hline \multirow{2}{*}{38} & $\begin{array}{l}\text { Pemasangan kamera pengintai untuk } \\
\text { melindungi infrastruktur }\end{array}$ & $\mathbf{3 . 6 7}$ & $\begin{array}{c}0.79 \\
8\end{array}$ & Tidak \\
\hline \multirow{2}{*}{39} & $\begin{array}{l}\text { Mempekerjakan penjaga keamanan untuk } \\
\text { melindungi infrastruktur }\end{array}$ & $\mathbf{3 . 6 4}$ & $\begin{array}{c}0.77 \\
3\end{array}$ & Tidak \\
\cline { 2 - 5 }
\end{tabular}

Responden menganggap 'kebijakan dalam hal penyediaan infrastruktur pendidikan dan pelatihan keamanan' menjadi yang paling 'penting'. Kabupaten Banyumas mengungkapkan 'kebijakan dalam hal inspeksi keamanan infrastruktur', 'jumlah insiden keamanan infrastruktur terkait di tahun keuangan terakhir', 'biaya insiden keamanan infrastruktur terkait' dan 'biaya mengamankan infrastruktur'. Hal tersebut tercantum dalam Catatan atas Laporan Keuangan.

Hasil penelitian ini tidak sesuai dengan penelitian yang dilakukan oleh Chatterjee (2011) yang menunjukkan bahwa responden menganggap 'biaya mengamankan infrastruktur' menjadi informasi keamanan infrastruktur yang paling 'penting'.
JURNAL

MANAJEMEN

INDONESIA

Vol. 15 - No.2

Agustus 2015

\section{Tabel 7.}

Indikator kinerja

informasi yang penting dan pengungkapannya di dalam LKPD

Kabupaten Banyumas

Tabel 8.

Informasi keamanan infrastruktur yang penting dan pengungkapannya di dalam LKPD Kabupaten Banyumas 


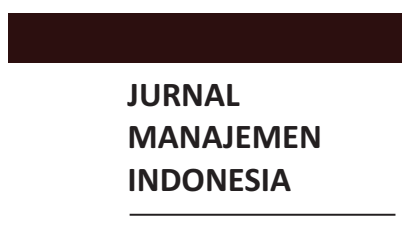

Vol. 15 - No.2

Agustus 2015

Tabel 9.

Total pengungkapan informasi infrastruktur yang dinilai 'penting' oleh para responden dalam LKPD Kabupaten Banyumas

\subsection{Total pengungkapan informasi infrastruktur yang dibutuhkan oleh responden di dalam LKPD Kabupaten Banyumas}

\begin{tabular}{l|l|l|l}
\hline & $\begin{array}{l}\text { Pengungkapan informasi } \\
\text { Nama }\end{array}$ & $\begin{array}{l}\text { Pengungkapan } \\
\text { infrastruktur di dalam } \\
\text { Pemerinta } \\
\text { LKPD (Jumlah/Persentasi) } \\
\text { di dalam LKPD } \\
\text { (Jumlah/Persentasi) } \\
\text { - Neuangan } \\
\text { (dari 17) }\end{array}$ & $\begin{array}{l}\text { Pengungkapan } \\
\text { informasi infrastruktur } \\
\text { (dari 23) }\end{array}$ \\
$\begin{array}{l}\text { Kabupaten } \\
\text { Banyumas }\end{array}$ & $8(47.1 \%)$ & $\begin{array}{l}\text { (Jumlah/Persentasi) } \\
\text { - Total (Keuangan+Non- } \\
\text { Keuangan) } \\
\text { (dari 40) }\end{array}$ \\
\hline
\end{tabular}

Pada Tabel 4.9, Kabupaten Banyumas mengungkapkan informasi infrastruktur keuangan yang dibutuhkan menurut responden yaitu sebanyak 8 dari 17 (47,1\%), informasi infrastruktur non-keuangan yang dibutuhkan menurut responden yaitu sebanyak 14 dari 23 (60,9\%), serta mayoritas informasi infrastruktur keuangan dan non-keuangan yang dibutuhkan menurut responden telah diungkapkan oleh pemerintah daerah Kabupaten Banyumas dengan total persentase sebesar 60\% (24 dari 40). Persentase informasi infrastruktur non-keuangan yang diungkapkan $(60,9 \%)$ lebih besar daripada pengungkapan informasi infrastruktur keuangan $(47,1 \%)$. Kabupaten Banyumas mengungkapkan informasi infrastruktur non-keuangan yang dianggap 'penting' menurut responden dengan persentase lebih besar

\subsection{Pembahasan}

Keseluruhan analisis LKPD Kabupaten Banyumas dalam hasil penelitian ini melaporkan bahwa mayoritas informasi infrastruktur keuangan menurut responden tidak diungkapkan oleh pemerintah daerah, sebagai persentase tertinggi dari pengungkapan infrastruktur keuangan yang dibutuhkan adalah 47,1\%. Hal ini menegaskan bahwa pengungkapan informasi infrastruktur keuangan di dalam LKPD Kabupaten Banyumas belum sesuai dengan kebutuhan responden. Oleh karena pengungkapan informasi infrastruktur keuangan di LKPD Kabupaten Banyumas $<75 \%$, maka $\mathbf{H 5}$ ditolak.

Hal tersebut menunjukkan bahwa pengungkapan informasi infrastruktur pada Laporan Keuangan Pemerintah Kabupaten Banyumas masih memiliki banyak kekurangan. Ini sejalan dengan penelitian yang dilakukan oleh Bikram Chatterjee (2011) yang menerangkan bahwa secara keseluruhan tidak terdapat hubungan positif antara aspek pengungkapan informasi infrastruktur keuangan menurut pengguna laporan tahunan dengan pengungkapan informasi keuangan pada laporan tahunan pemerintah lokal di New Zealand.

Keseluruhan analisis LKPD Kabupaten Banyumas dalam hasil penelitian ini melaporkan bahwa mayoritas informasi infrastruktur nonkeuangan menurut para responden diungkapkan oleh pemerintah daerah, sebagai persentase tertinggi dari pengungkapan infrastruktur non-keuangan yang dibutuhkan adalah 60,9\%. Hal ini menegaskan bahwa pengungkapan informasi infrastruktur non-keuangan di dalam LKPD Kabupaten Banyumas masih belum sepenuhnya sesuai dengan kebutuhan responden. Oleh karena pengungkapan informasi infrastruktur non-keuangan di LKPD Kabupaten Banyumas $<75 \%$, maka H6 ditolak. 
Hal tersebut menunjukkan bahwa pengungkapan informasi infrastruktur pada Laporan Keuangan Pemerintah Kabupaten Banyumas belum cukup baik dan lengkap karena masih memiliki kekurangan terhadap beberapa informasi penting yang belum diungkapkan. Ini sejalan dengan penelitian yang dilakukan oleh Bikram Chatterjee (2011) yang menerangkan bahwa secara keseluruhan tidak terdapat hubungan positif antara aspek pengungkapan informasi infrastruktur non-keuangan menurut pengguna laporan tahunan dengan pengungkapan informasi non-keuangan pada laporan tahunan pemerintah lokal di New Zealand.

Total analisis keuangan dan non-keuangan dari LKPD Kabupaten Banyumas dalam hasil penelitian ini memberikan keseluruhan sejauh mana pengungkapan informasi infrastruktur yang dibutuhkan oleh pemerintah daerah Kabupaten Banyumas menurut para responden. Persentase tertinggi dari pengungkapan total informasi infrastruktur yang dibutuhkan menurut para responden adalah adalah $60 \%$. Hal ini menegaskan bahwa secara keseluruhan pengungkapan informasi infrastruktur di dalam LKPD Kabupaten Banyumas masih belum sepenuhnya sesuai dengan kebutuhan responden.

\subsection{Faktor-Faktor yang Mempengaruhi Pelaporan Infrastruktur dalam LKPD Kabupaten Banyumas}

Bagian ini menjelaskan tentang faktor-faktor yang mempengaruhi pelaporan infrastruktur dalam LKPD Kabupaten Banyumas. Sebagaimana dinyatakan sebelumnya bahwa Hipotesis 5 dan Hipotesis 6 ditolak dalam kaitannya dengan aspek pengungkapan informasi infrastruktur keuangan di dalam LKPD Kabupaten Banyumas:

H5 : Aspek pengungkapan informasi infrastruktur keuangan di dalam LKPD Kabupaten Banyumas telah sesuai dengan kebutuhan pengguna.

H6 : Aspek pengungkapan informasi infrastruktur non-keuangan di dalam LKPD Kabupaten Banyumas telah sesuai dengan kebutuhan pengguna.

Penolakan dari kedua hipotesis (H5 dan H6) menunjukkan bahwa aspek pengungkapan informasi infrastruktur keuangan dan non-keuangan di dalam LKPD Kabupaten Banyumas belum sesuai dengan kebutuhan pengguna. Hasil tersebut memotivasi penelitian ini untuk mengkonfirmasi pengungkapan LKPD dengan mewawancarai pengguna LKPD Kabupaten Banyumas khususnya investor, untuk mendapatkan informasi tentang faktorfaktor yang mempengaruhi pelaporan infrastruktur dalam LKPD Kabupaten Banyumas.

Pengguna LKPD dimintai pendapat mengenai faktor-faktor yang mempengaruhi pemerintah daerah dalam melaporkan informasi infrastruktur tertentu pada LKPD Kabupaten Banyumas dan bagaimana pengungkapan informasi infrastruktur dalam LKPD dapat diperbaiki untuk memenuhi kebutuhan informasi pengguna LKPD.

Responden 1 tidak yakin tentang faktor-faktor yang mempengaruhi pelaporan informasi dalam LKPD Kabupaten Banyumas. Responden menyatakan bahwa LKPD Kabupaten Banyumas dapat diperbaiki melalui kritik dan saran dari pengguna LKPD. Masukan ini dapat dengan mudah diperoleh jika pemerintah daerah memberikan "kesempatan dan fasilitas" bagi pengguna LKPD yang akan memberikan kritik dan saran. Hal tersebut akan memberi masukan kepada pemerintah daerah dengan “...data yang lebih baik dan lebih lengkap" tentang informasi yang dibutuhkan oleh pengguna LKPD dalam LKPD Kabupaten Banyumas. 
JURNAL

MANAJEMEN

INDONESIA

Vol. 15 - No.2

Agustus 2015
Responden 2 menyatakan bahwa faktor utama yang mempengaruhi pemerintah daerah dalam menyusun LKPD adalah 'pembaca' LKPD tersebut. Responden melanjutkan bahwa pembaca seperti 'lembaga keuangan', 'investor', atau 'masyarakat umum'. Responden menyatakan bahwa pemerintah daerah Kabupaten Banyumas dapat memperbaiki LKPD dengan membuka 'ruang komunikasi' untuk menerima kritik dan saran dari masyarakat. Beliau juga menyatakan bahwa masyarakat dapat mempengaruhi pemerintah daerah dalam melaporkan informasi yang dibutuhkan pada LKPD salah satunya mungkin dengan menghubungi Bupati agar dapat dipertimbangkan.

Responden 3 menyatakan bahwa faktor utama yang mempengaruhi pelaporan infrastruktur pemerintah daerah Kabupaten Banyumas adalah: informasi yang diperlukan oleh BPK dan informasi yang harus dilaporkan menurut Standar Akuntansi Pemerintahan serta kebijakan pemerintah daerah. Responden menambahkan bahwa "...mungkin para dewan sebagai wakil kami sudah memberikan rekomendasi kepada pegawai pengelola pemerintah daerah dalam hal pelaporan keuangan pemerintah daerah". Responden 3 menyatakan lebih lanjut bahwa faktor lain yang mempengaruhi pemerintah daerah untuk melaporkan informasi infrastruktur tertentu dalam LKPD Kabupaten Banyumas adalah Dinas Pendapatan, Pengelolaan Keuangan dan Aset Daerah yang menyusun laporan tersebut. Responden menyatakan bahwa jika pihak luar terlibat dalam penyusunan LKPD “... mereka mungkin mampu menyusun informasi pada LKPD dengan lebih baik dalam hal informasi yang lebih lengkap dan luas". Responden menyatakan bahwa pelaporan infrastruktur pemerintah daerah dapat diperbaiki "...jika ada seseorang yang sedang membaca LKPD kemudian memiliki kritik dan saran terhadap sesuatu yang harus diperbaiki di dalam LKPD tersebut..." maka pembaca harus mengomunikasikan pendapatnya kepada "...penyusun atau pegawai" dari pemerintah daerah.

Responden 4 menyatakan bahwa dua faktor yang mempengaruhi pelaporan infrastruktur pemerintah daerah Kabupaten Banyumas adalah: “...apakah yang disyaratkan oleh Standar Akuntansi Pemerintahan dan apakah yang diinginkan BPK, serta apa yang harus dilakukan agar mendapat laporan wajar dari BPK". "Jadi masih banyak yang perlu dipikirkan, daripada hanya menunggu kritik dan saran dari pembaca". Responden menambahkan bahwa pembaca LKPD mungkin "...bisa bertemu secara langsung dengan penyusun LKPD di pemda bila memiliki kritik dan saran mengenai pengungkapan di dalam LKPD". Namun, "...mungkin akan selalu ada perbandingan dari penyusun mengenai besarnya biaya untuk mengungkapkan suatu informasi tersebut...".

Responden 5 menyatakan bahwa faktor utama yang mempengaruhi pelaporan keuangan pemerintah daerah adalah “...pengalaman dan pertimbangan profesional dari pegawai pemerintah daerah dan rekomendasi dari DPRD..." yang dihubungkan dengan Standar Akuntasi Pemerintahan. Faktor lainnya berasal dari 'kelompok masyarakat', yaitu ".....apa yang mungkin diinginkan dari setiap kelompok masyarakat...". 
Faktor utama yang mempengaruhi pengungkapan informasi infrastruktur di dalam LKPD Kabupaten Banyumas adalah: rekomendasi DPRD, Standar Akuntansi Pemerintahan, rekomendasi Badan Pemeriksa Keuangan dan Kebijakan Pemerintah Daerah. Penelitian ini sesuai dengan Furqan (2012) yang menyebutkan bahwa pengawasan dapat dilakukan oleh DPRD, sesuai dengan fungsi DPRD sebagai lembaga perwakilan rakyat. Rekomendasi diberikan oleh DPRD pada saat LKPJ, agar dapat memberikan implikasi yang lebih baik terhadap kinerja keuangan dan non-keuangan dari kepala daerah dan pemda.

Sesuai dengan Undang-undang Nomor 15 Tahun 2004 tentang Pemeriksaan Tanggung Jawab dan Pengelolaan Keuangan Negara, Lembaga yang berwenang untuk melakukan pemeriksaan atas laporan pertanggungjawaban tersebut adalah Badan Pemeriksa Keuangan (BPK). Pemerintah wajib mempertanggungjawabkan pelaksanaan APBD, baik dalam bentuk laporan keuangan (financial accountability) maupun laporan kinerja (performance accountability). Laporan keuangan disusun dan disajikan sesuai dengan Standar Akuntansi Pemerintahan (SAP), sedangkan Laporan Kinerja disusun sesuai dengan Peraturan Pemerintah yang mengatur tentang Laporan Kinerja instansi pemerintah.

Hasil penelitian ini sesuai dengan penelitian yang dilakukan oleh Chatterjee (2011) yang menyebutkan bahwa faktor utama yang mempengaruhi pengungkapan informasi infrastruktur pada pemerintah daerah Selandia Baru dalam laporan tahunan yang diidentifikasi oleh responden adalah pertimbangan profesional penyusun informasi infrastruktur dan persyaratan legislatif.

\section{KESIMPULAN DAN IMPLIKASI}

\subsection{Kesimpulan}

Berdasarkan hasil penelitian dapat disimpulkan bahwa:

1. Kebutuhan investor dalam berinvestasi di Kabupaten Banyumas adalah iklim investasi yang baik terutama dalam hal ketersediaan infrastruktur, ketersediaan sarana komunikasi, pelayanan pajak, pelayanan perizinan, informasi perkembangan pariwisata, sumber daya manusia, informasi lelang, peraturan daerah tentang investasi, dan informasi kegiatan pemerintah daerah.

2. Informasi yang digunakan investor di dalam LKPD Kabupaten Banyumas dalam pengambilan keputusan investasi adalah kebijakan pemerintah dibidang investasi, perpajakan, serta ekspor impor; evaluasi pelayanan yang diberikan pemda; informasi ketersediaan infrastruktur; informasi potensi unggulan daerah; prediksi pertumbuhan ekonomi daerah; perencanaan pemda beberapa tahun ke depan; prediksi pertumbuhan pendapatan pemda; dan informasi mengenai opini audit BPK atas LKPD.

3. Terdapat hubungan antara pembaca/bukan pembaca LKPD dengan kategori responden.

4. Terdapat hubungan antara kategori responden dengan alasan membaca LKPD.

5. Terdapat hubungan antara pentingnya informasi infrastruktur dengan kategori responden pembaca LKPD. 
JURNAL

MANAJEMEN

INDONESIA

Vol. 15 - No.2

Agustus 2015
6. Tidak terdapat hubungan antara waktu yang dibutuhkan untuk membaca LKPD dengan pentingnya informasi infrastruktur.

7. Aspek pengungkapan informasi infrastruktur keuangan di dalam LKPD Kabupaten Banyumas belum sesuai dengan kebutuhan pengguna karena LKPD hanya mengungkapkan sebesar $47,1 \%$ (kurang dari 75\%) dari informasi infrastruktur keuangan yang dibutuhkan oleh pengguna.

8. Aspek pengungkapan informasi infrastruktur non-keuangan di dalam LKPD Kabupaten Banyumas belum sepenuhnya sesuai dengan kebutuhan pengguna karena LKPD hanya mengungkapkan sebesar $60,9 \%$ (kurang dari 75\%) dari informasi infrastruktur nonkeuangan yang dibutuhkan oleh pengguna.

9. Faktor utama yang mempengaruhi pengungkapan informasi infrastruktur di dalam LKPD Kabupaten Banyumas adalah: rekomendasi DPRD, Standar Akuntansi Pemerintahan, rekomendasi Badan Pemeriksa Keuangan dan Kebijakan Pemerintah Daerah.

4.2. Implikasi

Penelitian ini dapat memberikan implikasi kepada:

1. Bagi Lingkungan Akademika

Penelitian ini memberikan sumbangan informasi mengenai pengungkapan informasi infrastruktur keuangan dan nonkeuangan yang dibutuhkan dalam LKPD serta memberikan sumbangan terhadap perkembangan ilmu akuntansi pemerintahan.

2. Bagi Pemerintah Daerah

Implikasi penelitian ini adalah pemerintah daerah Kabupaten Banyumas diharapkan dapat mengungkapkan informasi infrastruktur keuangan dan non-keuangan yang dibutuhkan menurut para responden, sehingga Kabupaten Banyumas dapat menyusun laporan keuangan yang lebih baik dan melengkapi informasi yang belum tersaji dalam LKPD.

3. Bagi Pengguna LKPD

Penelitian ini dapat menjadi referensi kepada para pengguna LKPD untuk melihat sejauh mana kinerja, pertanggungjawaban, transparansi, dan akuntabilitas pemerintah daerah dalam melayani kepentingan berbagai kelompok masyarakat terutama dalam hal informasi infrastruktur serta dapat dijadikan bahan pertimbangan oleh para investor atau pelaku bisnis yang sedang berinvestasi atau akan memutuskan untuk menanamkan investasi di Kabupaten Banyumas.

4. Bagi Penelitian Selanjutnya

Penelitian ini dilakukan masih terbatas pada Kabupaten Banyumas dan terbatas pada informasi infrastruktur yang dilaporkan, sehingga untuk penelitian selanjutnya dapat memperluas lokasi penelitian baik pada beberapa pemerintah daerah atau pemerintah propinsi, selain itu untuk penelitian selanjutnya juga dapat meneliti informasi-informasi lain yang diungkapkan di dalam LKPD sehingga dapat melengkapi informasi yang terkandung dalam laporan keuangan tersebut. 


\section{DAFTAR PUSTAKA}

Bank Dunia. 1994. World Bank Development Report 1994. Oxford University Press.

Bryman, A. 2006. Integrating Quantitative and Qualitative Research: How Is It Done?. Qualitative Research.6 (1).97-113.

Chatterjee, Bikram. 2011. Infrastructure Reporting by New Zealand Local Governments. Thesis. Fakultas Pemerintahan dan Bisnis Universitas Canberra: Australia.

Conrad, K. dan Seitz, H. 1994. The economic benefits of public infrastructure. Applied Economics 26 (4). 303-311.

Furqan, Andi Chairil. 2012. Siklus Pengelolaan Keuangan Negara.

Laporan Keuangan Pemerintah Daerah (LKPD) Kabupaten Banyumas Tahun 2004-2010.

Marzuki. 2005. Metodologi Riset. Yogyakarta: Ekonisia.

Pallot, J. (1997). Infrastructure Accounting for Local Authorities: Technical Management and Political Context. Financial Accountability \& Management, 13 (3). 225-242.

Peraturan Menteri Dalam Negeri Nomor 13 Tahun 2006, tentang Pedoman Pengelolaan Keuangan Daerah.

Peraturan Pemerintah Republik Indonesia Nomor 24 Tahun 2005 tentang Standar Akuntansi Pemerintahan.

Peraturan Pemerintah Republik Indonesia Nomor 58 Tahun 2005 tentang Pengelolaan Keuangan Daerah.

Peraturan Pemerintah Republik Indonesia Nomor 71 Tahun 2010 tentang Standar Akuntansi Pemerintahan.

Sjafrizal. 2008. Ekonomi Regional Teori Dan Aplikasi. Padang: Baduose Media.

Tashakkori, A. dan Teddlie C. 2003. Handbook of Mixed Methods in Social \&. Behavioral Research. Thousand Oaks: Sage.

Undang-Undang Republik Indonesia Nomor 17 Tahun 2003 tentang Keuangan Negara.

Undang-Undang Republik Indonesia Nomor 1 Tahun 2004 tentang Perbendaharaan Negara.

Undang-Undang Republik Indonesia Nomor 15 Tahun 2004 tentang Pemeriksaan Pengelolaan dan Tanggung Jawab Keuangan Negara.

Undang-Undang Republik Indonesia Nomor 25 Tahun 2004 tentang Sistem Perencanaan Pembangunan Nasional. 
JURNAL

MANAJEMEN

INDONESIA

Vol. 15 - No.2

Agustus 2015 